\title{
PENGARUH KECERDASAN EMOSI TERHADAP STRES KERJA PADA PENGAJAR MUDA DI GERAKAN INDONESIA MENGAJAR
}

Fitri Lestari Issom*

*Universitas Negeri Jakarta

**Universitas Negeri Jakarta
Fiany Aprilia**

DOI: https://doi.org/10.21009/JPPP.081.01

\section{Alamat Korespondensi:}

fitrilestari@gmail.com

\begin{abstract}
The present study attempted to analyze the impact of emotional intelligence towards job stress of Pengajar Muda in Gerakan Indonesia Mengajar. The approach used in the study is quantitative approach. The population of the study was the Pengajar Muda in Gerakan Indonesia Mengajar and the sample of the study was 72 people from Pengajar Muda class of 14, 15, and 16. The instrument used in this study is a job stress scale from Robbins and Emotional Intelligence Questionnaire from Goleman. The data were analyzed using regression analysis. The result of analytics regression is $F$ in the amount of 15,462 with value $p$ in the amount 0,000 $<0,05$ is significant, the study revealed that there is negative impact of emotional intelligence towards job stress which indicates that the higher the emotional intelligence means the lower the job stress, and vice versa. The effect of emotional intelligence showed at 16,9\% towards job stress.
\end{abstract}

\section{Keywords}

emotional intelligence, job stress, pengajar muda, gerakan indonesia mengajar

\section{Pendahuluan}

Pendidikan adalah salah satu hal yang penting dalam pembangunan nasional. Pendidikan merupakan kunci untuk meningkatkan sumber daya manusia. Pendidikan dengan kualitas yang baik diharapkan dapat menghasilkan anak didik yang mempunyai pemikiran-pemikiran yang luas tentang aspek-aspek di dunia. (Aminah dkk, 2016). Khususnya pendidikan di Indonesia karena anak didik yang baik akan menciptakan perkembangan yang baik untuk negeri ini. Tetapi fakta yang terdapat di lapangan adalah masalah pemerataan pendidikan di Indonesia masih menjadi hal yang tidak terpecahkan. Pemerataan pendidikan ini merupakan persoalan penyediaan kesempatan bagi tiap individu untuk memperoleh pendidikan, masalah ini tergambarkan karena melihat ketimpangan antara pendidikan di kota dan di pelosok daerah. Minimnya sekolah di pelosok daerah merupakan salah satu gambaran pendidikan Indonesia yang belum merata. (Aprilia, 2014).

Salah satu alasan kesenjangan pendidikan di kota dan desa adalah guru-guru belum tersebar merata. Papua Barat misalnya melaporkan kekurangan guru sebanyak 2.629 orang. Begitu pula Papua yang masih perlu guru sebanyak 5.151 orang (Dewimerdeka, 2015). Data ini menggambarkan bahwa ketimpangan antar daerah yang satu dengan yang lainnya masih ada dan 
perbedaan yang sangat signifikan. Padahal, jika dilihat dari rasio guru ini, Indonesia mempunyai angka yang seimbang menurut data UNESCO, Indonesia merupakan negara dengan rasio gurumurid yang cukup ideal dibanding negara lain. Rasio guru-murid SD di Indonesia 1:16, lebih baik dibanding Brazil (1:22), Jepang (1:18), serta Prancis (1:18) (Linggasari, 2014). Ini mengindikasikan bahwa sebenarnya pemerataan sumber daya pengajar ini dapat direalisasikan jika pemerintah dapat mengatur penyebaran. Tidak hanya pemerintah tetapi dari pengajarnya sendiri yang dapat membangun kesadaran untuk meningkatkan pendidikan dan menyebarkan ilmu di daerah manapun.

Alasan penyebaran guru ini penting adalah peran guru dalam dunia pendidikan menjadi kunci utama kesuksesan sistem pendidikan yang telah dibuat. Guru adalah yang menjadi titik penentu dalam melakukan kegiatan dalam rangka meningkatkan mutu pendidikan (Direktorat Tenaga Kependidikan, 2008). Guru adalah seseorang yang menjadi penentu sekaligus mengembangkan dan meningkatkan ilmu yang ada pada anak didik sehingga tujuan dari pendidikan pun tercapai. Guru yang mempunyai kemampuan mengajar dan kinerja yang baik akan membawa pengaruh yang positif terhadap pembelajaran (Riyani, 2012). Maka dari itu, pemerataan guru ke pelosok daerah adalah hal yang penting untuk meningkatkan pendidikan dalam keseluruhan daerah di Indonesia.

Saat ini sudah terdapat program yang mengirim para lulusan muda untuk mengajar ke daerahdaerah terpencil di Indonesia. Program ini dinamakan Gerakan Indonesia Mengajar. Tujuan dari program ini adalah agar pendidikan dasar dapat diterima oleh seluruh anak di Indonesia yang tinggal dimanapun karena pendidikan adalah hak yang wajib diterima oleh seluruh rakyat Indonesia. Tujuan yang lain juga program ini berjalan untuk memenuhi kebutuhan guru yang masih kurang di daerah-daerah pelosok Indonesia. Tugas pengajar dalam program ini tidak hanya mengajarkan pelajaran saja terhadap anak didik, tetapi juga mempunyai tugas untuk membangun dan mengembangkan daerah masing-masing, serta membantu agar masyarakat lebih peduli lagi terhadap masa depan pendidikan dan generasi penerus Indonesia (Indonesia Mengajar, 2018).

Gerakan Indonesia Mengajar menggunakan sebutan pengajar bukan guru, dapat dijelaskan bahwa terdapat perbedaan antara guru dan pengajar. Disebutkan dalam Undang Undang Republik Indonesia nomor 14 tahun 2006 bab II Pasal 6 bahwa kedudukan guru dan dosen sebagai tenaga profesional bertujuan untuk melaksanakan sistem pendidikan nasional dan mewujudkan tujuan pendidikan nasional, yaitu berkembangnya potensi peserta didik agar menjadi manusia yang beriman dan bertakwa kepada Tuhan Yang Maha Esa, berakhlak mulia, sehat, berilmu, cakap, kreatif, mandiri, serta menjadi warga negara yang demokratis dan bertanggung jawab. Kemudian pada bab III Pasal 20 disebutkan bahwa dalam melaksanakan tugas keprofesionalan, guru berkewajiban (1) merencanakan pembelajaran, melaksanakan proses pembelajaran yang bermutu, serta menilai dan mengevaluasi hasil pembelajaran, (2) meningkatkan dan mengembangkan kualifikasi akademik dan kompetensi secara berkelanjutan sejalan dengan perkembangan ilmu pengetahuan, teknologi, dan seni, (3) bertindak objektif dan tidak diskriminatif atas dasar pertimbangan jenis kelamin, agama, suku, ras, dan kondisi fisik tertentu, atau latar belakang keluarga, dan status sosial ekonomi peserta didik dalam pembelajaran, (4) menjunjung tinggi peraturan perundangundangan, hukum dan kode etik guru, serta nilainilai agama dan etika, (5) memelihara dan memupuk persatuan dan kesatuan bangsa.

Adapun tugas pengajar muda di Gerakan Indonesia Mengajar mencakup tiga bagian yaitu yang pertama adalah tugas yang berhubungan dengan kepala sekolah, guru, dan murid-murid yaitu pengajar terlibat dalam kegiatan mengajar melalui media pembelajaran yang kreatif dan mendorong kepala sekolah serta guru untuk ikut 
serta dalam berbagai kegiatan tersebut. Lalu, yang kedua adalah tugas yang berhubungan dengan masyarakat yaitu pengajar terlibat dalam mengembangkan dan memajukan masyarakat di desa melalui program-program yang sudah dibentuk. Kemudian, yang ketiga adalah tugas yang berhubungan dengan desa yaitu pengajar berhubungan dengan pemerintah daerah setempat untuk bekerja sama dalam membangun desa menjadi lebih baik (Gerakan Indonesia Mengajar, 2016)

Tanggung jawab dan tugas pengajar yang dijabarkan di atas ini yang jika tidak dikontrol dengan baik akan berubah menjadi tekanan besar pada pengajar. Tanggung jawab pengajar di pelosok daerah lebih besar karena tidak sekedar mengajar tetapi juga membantu kepala sekolah dan guru yang berasal dari daerah tersebut untuk mengembangkan proses belajar mengajar di daerah tersebut dan untuk kemajuan di daerah. (Indonesia Mengajar, 2018). Tanggung jawab yang besar ini diikuti dengan tekanan yang dialami oleh pengajar di pelosok daerah karena berbagai perbedaan antara pengajar dengan masyarakat sekitar. Berdasarkan hasil wawancara awal yang dilakukan peneliti dengan tiga pengajar muda yang sudah menyelesaikan tugas hambatan yang dapat terjadi di daerah seperti perbedaan bahasa, makanan, budaya, dan lingkungan. Tekanan ini dapat berkembang menjadi stres kerja pada pengajar. Stres kerja sendiri adalah ketegangan yang sering dialami oleh individu yang dapat mengganggu situasi kerja serta konsentrasi dalam menyelesaikan tugas (Rustiana \& Cahyati, 2012).

Stres kerja yang dialami oleh pengajar di kota dengan pengajar yang mengajar di pelosok daerah tentu berbeda. Kondisi lingkungan, budaya, bahasa, sarana dan prasarana yang kurang memadai dan berbeda dengan di kota menjadi salah satu sumber dari stres pengajar. Disebutkan juga pengajar yang dikirim ke daerah memang memiliki kendala yang berat seperti medan, ketersediaan listrik, infrastuktur yang menantang
(Medistiara, 2016). Menurut Howard dan Jhonson (2002) stres pada seorang pengajar dapat timbul dari faktor lingkungan kerja yang buruk dan tidak mendukung proses belajar mengajar.

Oleh karena itu, seorang pengajar harus mempunyai kepribadian yang matang, tegar, dan kemampuan untuk menghadapi masalah yang dihadapi. Menurut Hurrel (dalam Munandar,2001) faktor-faktor pekerjaan yang dapat menimbulkan stres dikelompokkan dalam lima kategori besar yaitu faktor-faktor intrinsik dalam pekerjaan, peran dalam organisasi, pengembangan karier, hubungan dalam pekerjaan serta struktur dan organisasi. Pertama, kategori faktor-faktor intrinsik dalam pekerjaan adalah fisik dan tugas, untuk fisik misalnya kebisingan, panas sedangkan tugas mencakup beban kerja, kerja malam dan penghayatan dari resiko dan bahaya.

Stres kerja ini dapat berpengaruh pada kemampuan pengajar untuk menyampaikan ilmu kepada anak didiknya terlebih lagi mereka memiliki tugas tambahan untuk mengembangkan daerah dimana mereka ditugaskan. Konflik dan tekanan yang dirasakan oleh individu di tempat kerja merupakan hasil dari individu yang tidak mampu dalam mengendalikan emosi, menumbuhkan motivasi dalam dirinya, dan memahami perasaan seseorang di sekitarnya (Farhani \& Novianingtyas, 1997). Menurut Mischel (dalam Prabowo \& Setyorini, 2005) bahwa individu yang dapat menahan dan mengendalikan stres, siap untuk mengambil resiko dalam pekerjaan, percaya dengan kemampuan dirinya, dapat menyelesaikan masalah yang terjadi, serta mempunyai solusi untuk kesulitan yang dihadapi merupakan individu yang memiliki kecerdasan emosi yang baik.

Individu dapat menghindari dan tidak mengalami stres serta agar individu mempunyai kemampuan adaptasi yang baik dengan lingkungan baru adalah kecerdasan emosi yang baik (Adeyemo \& Ogunyemi, 2003). Ini dapat dikaitkan dengan pengajar muda di Gerakan Indonesia Mengajar 
yang harus tinggal dalam jangka waktu lama di lingkungan dan budaya baru di daerah penempatannya, maka dari itu hal untuk membantu adaptasi tersebut adalah kecerdasan emosi. Individu yang dapat dengan mudah menangani stres dalam pekerjaanya yang berupa fisiologis maupun psikologis adalah jika individu tersebut mempunyai kemampuan mengelola emosi diri sendiri dan rekan kerjanya (Kazi, 2013). Pada penjelasan di atas dapat diartikan bahwa stres dapat dikurangi dengan adanya kecerdasan emosi. Goleman (1999) mengemukakan bahwa kecerdasan emosi dalam dunia kerja sangat penting karena banyak bidang pekerjaan yang dapat berjalan dengan menggunakan cara pikir analistis dibandingkan dengan mengginakan perasaan atau emosi.

Menurut Robbins (2008), stres adalah kondisi dinamik yang di dalamnya individu menghadapi peluang, kendala, atau tuntutan yang terkait denga apa yang sangat diinginkannya dan yang hasilnya dipersepsikan sebagai tidak pasti tetapi penting.

Menurut Robbins (2008) pula, aspek-aspek stres kerja dibagi menjadi tiga aspek yaitu: (1) gejala psikologis yaitu stres kerja yang dialami oleh individu dapat berdampak pada sisi psikologisnya. Berbagai aspek psikologis yang dapat menjadi acuan dalam stres kerja adalah rasa cemas, rasa bosan, penurunan rasa percaya diri, kehilangan daya konsentrasi, penurunan harga diri, dan rasa gelisah, (2) gejala fisik yaitu selain psikologis, aspek fisik juga hal yang berkaitan erat dengan stres kerja yang timbul dari individu tersebut. Berbagai aspek fisik dalam stres kerja adalah mudah lelah secara fisik, lebih sering berkeringat, kepala pusing, gangguan lambung, mudah terluka, serta masalah tidur seperti sulit tidur atau kebanyakan tidur, (3) gejala perilaku yaitu aspek perilaku juga merupakan hal yang penting dalam menganalisa stres kerja pada individu. Berbagai aspek perilaku yang dapat dilihat adalah menunda atau menghindari pekerjaan, penurunan prestasi dan produktifitas, meningkatnya penggunakan minuman keras atau mabuk, meningkatnya frekuensi absensi, meningkatnya perilaku yang beresiko tinggi seperti berjudi, peningkatan agresifitas dan kriminalitas, penurunan kualitas hubungan interpersonal dengan keluarga dan teman.

Goleman, yang mengemukakan bahwa kecerdasan emosi adalah kemampuan seseorang untuk memahami perasaan diri sendiri dan perasaan orang lain, kemampuan untuk mendorong diri sendiri untuk mencapai tujuan, dan kemampuan untuk mengontrol emosi dengan baik dalam diri sendiri dan hubungan antara orang lain (Goleman, 1999).

Goleman (1999), membagi kecerdasan emosi menjadi berbagai aspek, yaitu: aspek pertama, kesadaran diri yaitu kemampuan individu dalam memahami apa yang dirasakan dalam suatu kondisi. Pemahaman terhadap perasaan tersebut dapat membuat individu mempunyai kemampuan untuk mengambil keputusan terhadap dirinya sendiri, dapat mengetahui cara untuk mengatasi dan menyelesaikan masalah yang dialami oleh individu tersebut. Kedua, aspek pengaturan diri yaitu kemampuan individu untuk mengelola emosi pada dirinya sehingga individu tersebut dapat melaksanakan segala sesuatu dengan baik dan dapat mencapai tujuan. Individu paham dengan perasaan dan kata hati serta dapat mengatur dirinya untuk menunda suatu hal yang tidak bermanfaat dan hanya menjadi hambatan pencapaian tujuannya. Aspek yang ke-3 adalah motivasi, yaitu kemampuan individu untuk dapat mendorong diri nya sendiri untuk mencapai tujuan. Tidak hanya mendorong tetapi juga menemukan cara untuk mendapatkan hasil akhir yang diinginkan. Saat keberhasilan tidak didapatkan juga, individu tersebut mampu mendorong dirinya untuk bangkit kembali dan tidak terpuruk dalam rasa frustasi. Keempat adalah aspek empati, yaitu kemampuan individu untuk merasakan apa yang dirasakan oleh orang laing yang ada disekitarnya. Dengan mampu merasakan dan memahami posisi dan perasaan 
orang sekitar membuat individu dapat berinteraksi dengan baik dan mengetahui cara untuk keluar dari berbagai masalah dan mengasah tingkat kepekaan pada lingkungan. Dapat membangun penyesuaian diri dengan orang lain dan saling percaya. Kelima, keterampilan sosial, yaitu kemampuan individu untuk menjalin hubungan dengan orang lain, berinteraksi dengan baik, dan mengelola situasi yang terdapat di lingkungan sekitar. Berhubungan yang baik dengan orang sekitar membuat individu dapat membentuk jaringan sosial yang baik. Jaringan sosial yang baik dan kerap berkomunikasi dengan orang membuat individu dapat bekerja sama, berdiskusi, dan menyelesaikan masalah yang terjadi di lingkungan sekitarnya.

\section{Metode Penelitian}

\section{Desain Penelitian}

Penelitian ini adalah penelitian kuantitatif yang mengeksplorasi pengaruh kecerdasan emosi terhadap stress kerja.

\section{Subjek Penelitian}

Populasi yang disasar dalam penelitian ini adalah pengajar muda di Gerakan Indonesia Mengajar. Subjek penelitian ini adalah pengajar muda di Gerakan Indonesia Mengajar angkatan 14, 15 dan 16, yang terdiri dari 28 laki-laki dan 44 perempuan dengan rentang usia 22-30 tahun. Teknik pengambilan sampel yang digunakan dalam penelitian ini adalah non-probability sampling dengan teknik purposive sampling, yaitu dengan menggunakan pertimbangan karakteristik spesifik dalam pemilihan sampel.

\section{Variabel Penelitian}

Variabel yang dieksplorasi pada penelitian ini terbagi menjadi dua, yaitu variabel berbas dan variabel terikat. Variabel bebas pada penelitian ini adalah kecerdasan emosi, sedangkan variabel terikat-nya adalah stress kerja. Secara keseluruhan, penelitian ini menguji pengaruh kecerdasan emosi terhadap stress kerja pada pengajar muda Gerakan
Indonesia Mengajar.

\section{Alat Ukur Penelitian}

Pada penelitian ini, ada dua instrumen yang digunakan, yaitu alat ukur tentang stress kerja dan alat ukur tentang kecerdsan emosi. Berikut adalah pemaparan untuk masing-masing alat ukur.

Variabel stress kerja diukur dengan menggunakan instrumen yang telah dikonstruk oleh Anisa (2014). Instrumen tersebut terdiri dari 42 butir pernyataan yang terdiri dari tiga dimensi stres kerja yang dikemukakan oleh Robbins, yaitu gejala fisik, gejala psikologis dan gejala perilaku. Pada penelitian ini, instrumen stres kerja yang digunakan hanya terdiri dari 34 butir pernyataan, setelah sebelumnya dilakukan uji coba terhadap subjek penelitian yang sesuai dengan kategori dan hasil analisis uji coba menggugurkan 8 butir karena ketidaksesuaian konteks.

Variabel kecerdasan emosi pada penelitian ini diukur dengan menggunakan instrument Emotional Intelligence Questionnaire yang dibuat oleh Daniel Goleman pada tahun 1999 dan dikeluarkan oleh Leading Across London-NHS. Instrumen kecerdasan emosi memiliki 51 butir pernyataan yang terdiri dari lima aspek kecerdasan emosi, yaitu: kesadaran diri, mengelola emosi, motivasi, empati, dan membina hubungan dengan orang lain. Pada penelitian ini, instrumen kecerdasan emosi yang digunakan hanya terdiri dari 43 butir, setelah sebelumnya dilakukan uji coba terhadap subjek penelitian yang sesuai dengan kategori dan hasil analisis data uji coba dengan menggunakan model Rasch dan menggugurkan 8 butir pernyataan.

\section{Prosedur Penelitian dan Analisis Data}

Data dikumpulkan dengan menggunakan kuesioner yang disebarkan secara langsung dalam bentuk fisik maupun dalam bentuk online (google form). Kuesioner penelitian ini disebarkan secara spesifik kepada pengajar muda Gerakan Indonesia Mengajar angkatan 14, 15 dan 16. Seluruh partisipan yang direkrut pada penelitian ini secara sukarela untuk turut berpartisipasi dalam penelitian ini. Data yang didapatkan selanjutnya dianalisis 
dengan menggunakan analisis regresi linier dengan menggunakan SPSS IBM versi 16.0. Analisis model Rasch untuk melakukan analisis item dilakukan dengan menggunakan Winstep versi 3.73. Uji normalitas, uji linearitas, uji korelasi dan uji hipotesis juga dilakukan untuk melihat kesesuaian analisis regresi yang dilakukan. Analisis deskriptif juga dilakukan untuk melihat gambaran demografi partisipan.

\section{Demografi Partisipan}

Jumlah partisipan dalam penelitian ini terdiri dari 72 partisipan yang terdiri dari 28 laki-laki dan 44 perempuan dengan rentang usia 22-30 tahun. Partisipan merupakan pengajar muda Gerakan Indonesia Mengajar yang berasal dari 3 angkatan, yaitu angkatan 14, 15, dan 16.

\section{Hasil Penelitian dan Diskusi}

Tabel 1. Data Distribusi Subjek Penelitian Berdasarkan Usia

\begin{tabular}{ccc}
\hline Usia (tahun) & $\mathbf{N}$ & Persentase \\
\hline 22 & 1 & $1,4 \%$ \\
23 & 13 & $18,1 \%$ \\
24 & 17 & $23,6 \%$ \\
25 & 17 & $23,6 \%$ \\
26 & 13 & $18,1 \%$ \\
27 & 7 & $9,7 \%$ \\
28 & 1 & $1,4 \%$ \\
29 & 2 & $2,8 \%$ \\
30 & 1 & $1,4 \%$ \\
Total & $\mathbf{7 2}$ & $\mathbf{1 0 0 , 0 \%}$ \\
\hline
\end{tabular}

Tabel 2. Data Distribusi Subjek Penelitian Berdasarkan Jenis Kelamin

\begin{tabular}{ccc} 
& N & Persentase \\
\hline Jenis Kelamin & & $38,9 \%$ \\
Laki-laki & 28 & $61,1 \%$ \\
Perempuan & 44 & $\mathbf{1 0 0 , 0 \%}$ \\
Total & $\mathbf{7 2}$ & \\
\hline
\end{tabular}

Tabel 1-3 memberikan gambaran subjek penelitian berdasarkan usia, jenis kelamin, dan angkatan di Gerakan Indonesia Mengajar. Secara keseluruhan, rentang usia partisipan penelitian ini adalah 22-30 tahun dengan partisipan berumur 24 dan 25 tahun paling banyak ditemukan berpartisipasi pada penelitian ini. Sebanyak 44 partisipan penelitian ini adalah perempuan, dan 22 lainnya adalah laki-laki.
Sekitar $42 \%$ partisipan pada penelitian ini merupakan Pengajar Muda angkatan 14, 38\% partisipan merupakan Pengajar Muda angkatan 15, dan sisanya (20\%) adalah Pengajar Muda angkatan 16.

Tabel 4 dan 5 memberikan gambaran kondisi stres kerja dan kecerdasan emosi partisipan penelitian ini. Secara keseluruhan, 38 partisipan (52.8\%) memiliki stress kerja tinggi, dan 34 partisipan lainnya $(47.2 \%)$ memiliki stress kerja 
rendah. Sebaliknya, 38 partisipan (52.8\%) (47.2\%) memiliki kecerdasan emosi tinggi.

memiliki kecerdasarn emosi rendah dan sisanya

Tabel 3. Data Distribusi Subjek Penelitian Berdasarkan Angkatan

\begin{tabular}{ccc}
\hline Angkatan & N & Persentase \\
\hline 14 & 30 & $41,7 \%$ \\
15 & 27 & $37,5 \%$ \\
16 & 15 & $20,8 \%$ \\
\hline Total & $\mathbf{7 2}$ & $\mathbf{1 0 0 , 0 \%}$ \\
\hline
\end{tabular}

Tabel 4. Kategori Stres Kerja

\begin{tabular}{cccc}
\hline Kategori Stres & Skor & Frekuensi & \multicolumn{2}{c}{ Persentase } \\
\hline Rendah & $<-2.97$ & 34 & $47,2 \%$ \\
Tinggi & $>-2.97$ & 38 & $52,8 \%$ \\
\hline Total & & $\mathbf{7 2}$ & $100 \%$ \\
\hline
\end{tabular}

\section{Pengujian Hipotesis}

Terdapat probabilitas stres kerja sebesar 0.928 dan kecerdasan emosi sebesar 0,338. Kriteria data bersdistribusi normal berdasarkan rumus kolmogrov-smirnov adalah apabila nilai $\mathrm{p}$ lebih besar dari $\alpha$. Pada perhitungan di atas didapatkan bahwa nilai $\mathrm{p}=0,928>\alpha=0,05$ dan $\mathrm{p}=0,338>\alpha$ $=0,05$. Maka kedua variabel tersebut berdistribusi normal. Pada variabel penelitian memiliki nilai $\mathrm{p}$ sebesar 0,000 . Artinya nilai $p=0,000<\alpha=0,05$.
Hal ini menunjukkan bahwa variabel stres kerja linear dengan variabel kecerdasan emosi dan terdapat hubungan yang signifikan antara stres kerja dan kecerdasan emosi.

Tabel 5. Kategori Kecerdasan Emosi

\begin{tabular}{cccr}
\hline Kategori Kecerdasan & Skor & Frekuensi & Persentase \\
\hline Rendah & $<-2.19$ & 38 & $52,8 \%$ \\
Tinggi & $>-2.19$ & 34 & $47,2 \%$ \\
\hline Total & & $\mathbf{7 2}$ & $100 \%$ \\
\hline
\end{tabular}

Dalam uji regresi menghasilkan nilai $\mathrm{F}$ hitung sebesar 15,462 sedangkan $\mathrm{F}$ tabel untuk sampel yang berjumlah 72 orang dengan taraf signifikansi
$0,05 \%$ adalah 3,12. Dalam hal ini $\mathrm{F}$ hitung $=15,462$ $>\mathrm{F}$ tabel $=3,12$ dan Nilai $\mathrm{p}=0,000<\alpha=0,05$ maka dapat diinterpretasikan bahwa terdapat 
pengaruh yang signifikan antara variabel kecerdasan emosi terhadap stres kerja dan dapat disimpulkan Ho ditolak dan Ha diterima. Dengan demikian variabel kecerdasan emosi dapat memprediksi stres kerja.

Besar pengaruh ( $R$ Square) variabel kecerdasan emosi terhadap stres kerja adalah sebesar 0,169 $(16,9 \%)$. Hal ini menunjukkan bahwa kecerdasan emosi mempengaruhi stres kerja sebesar 16,9\% dan sisanya $83,1 \%$ dipengaruhi oleh variabel lain yang tidak diteliti dalam penelitian ini.

Konstanta variabel stres kerja sebesar -1,652, sedangkan koefisiensi regresi kecerdasan emosi adalah sebesar $-0,599$. Berdasarkan perhitungan di atas, maka dapat dibuat persamaan regresi sebagai berikut :

$$
\mathrm{Y}=\mathrm{a}+\mathrm{bX}
$$

Stres kerja $=-1,652+(-0,599)$ kecerdasan emosi

Berdasarkan persamaan yang telah dituliskan, dapat disimpulkan bahwa terjadi hubungan yang negatif signifikan antara kecerdasan emosi dengan stres kerja. Koefisien regresi kecerdasan emosi sebesar -0,599 yang artinya jika kecerdasan emosi mengalami kenaikan satu satuan maka stres kerja akan mengalami penurunan sebesar 0,599.

Dalam penelitian ini terdapat 72 subjek penelitian yang terdiri dari Pengajar Muda angkatan 14, 15, dan 16. Dari subjek penelitian tersebut terdapat 38 orang subjek penelitian $(52,8 \%)$ dengan tingkat stres kerja yang tinggi dan terdapat 34 orang subjek penelitian $(47,2 \%)$ dengan tingkat stres kerja yang rendah. Lalu, pada kecerdasan emosi terdapat 34 orang subjek penelitian $(47,2 \%)$ yang memiliki tingkat kecerdasan emosi yang tinggi dan terdapat 38 orang subjek penelitian $(52,8 \%)$ dengan tingkat kecerdasan emosi yang rendah. Menurut Safrizal dan Noviati (2012), kecerdasan emosi mempunyai peran yang penting untuk individu dalam menjalankan kewajiban dan tugas serta dalam menghadapi masalah yang terjadi di kehidupan yang diakibatkan oleh tugas tersebut, individu yang mempunyai kecerdasan emosi yang baik diharapkan akan mempunyai daya tahan yang baik dan memiliki kemampuan untuk mengendalikan stres atau manajemen stres sehingga kemampuan berpikir dan suasana hati ketika menjalani tugas tidak terganggu.

Berdasarkan hasil penelitian yang telah dilakukan dari analisis regresi dapat disimpulkan bahwa Ha diterima dan Ho ditolak yang mengindikasikan terdapat pengaruh yang signifikan antara kecerdasan emosi terhadap stres kerja pada Pengajar Muda di Gerakan Indonesia Mengajar. Hasil dari arah pengaruh yaitu negatif yang diartikan jika kecerdasan emosi rendah, maka stres kerja akan tinggi. Begitu pula sebaliknya yaitu jika kecerdasan emosi tinggi maka stres kerja akan rendah. Pengaruh kecerdasan emosi terhadap stres kerja adalah sebesar 16,9\% sedangkan $83,1 \%$ lainnya dipengaruhi oleh faktor lain yang tidak diteliti dalam penelitian ini. Robbins dan Judge (2011) menyebutkan bahwa faktor yang mempengaruhi stres kerja adalah faktor lingkungan, faktor organisasi, dan faktor pribadi.

Penelitian ini menunjukkan hasil bahwa kecerdasan emosi mempunyai hubungan yang negatif dan signifikan dengan stres kerja. Hasil tersebut memiliki kesamaan dengan teori yang dikemukakan oleh Goleman (1999) yang menjelaskan bahwa dengan memiliki kecerdasan emosi seseorang dapat memotivasi diri, tidak mudah frustasi dan yang terpenting adalah mampu mengendalikan stres. Tingginya stres kerja dipengaruhi oleh kecerdasan emosi pada setiap individu, jika kecerdasan emosinya tinggi, kemampuan individu dalam mengelola stres baik. Dengan demikian, individu yang memiliki kecerdasan emosi yang tinggi akan selalu berperilaku positif dan produktif dalam melakukan pekerjaan.

Hubungan antara stres kerja dengan kecerdasan emosi juga mempunyai kesesuaian dengan studistudi yang telah dilakukan. Penelitian yang dilaksanakan oleh Kusumawati (2009) yang 
menunjukkan hasil bahwa terdapat hubungan negatif yang signifikan antara tingkat kecerdasan emosi dengan tingkat stres kerja perawat di IRD RSUP Dr. Soeradji Tirtonegoro Klaten dan mengungkapkan bahwa subjek penelitian yang memiliki stres kerja dengan kategori tinggi dapat disebabkan karena jumlah tuntutan yang semakin meningkat atau saat subjek penelitian memandang tuntutan kerja yang dihadapi sebagai masalah yang sulit atau mengancam. Penelitian yang dilaksanakan oleh Triana, Rahmi, dan Putra (2015) mendapatkan hasil bahwa terdapat korelasi negatif yang signifikan antara kecerdasan emosi dengan stres guru yang disertifikasi dan mengungkapkan bahwa guru-guru dengan kemampuan kecerdasan emosi yang baik dapat membuat mereka memiliki stres yang rendah.

Penelitian lainnya juga dilakukan oleh Noviati (2015) yang mempunyai hasil terdapat hubungan negatif yang signifikan antara kecerdasan emosi dengan stres kerja, dan juga mengungkapkan bahwa kecerdasan emosi memiliki beberapa aspek yang berhubungan dengan stres kerja misalnya adalah aspek mengelola emosi, aspek ini dapat menekan munculnya stres kerja karena individu mampu menangani emosinya sendiri sehingga tidak menimbulkan gejala stres kerja seperti kecemasan, pusing, gangguan metabolisme sampai pada bolos kerja. Dalam penelitian ini juga mengungkapkan bahwa orang yang tidak memiliki kemampuan dalam mengelola emosi tidak dapat menunjukkan sikap kerja yang positif dan tidak mampu menciptakan lingkungan kerja yang nyaman.

Hal ini selaras dengan pengertian kecerdasan emosi yaitu kemampuan mengatur suasana hati bertahan dalam menghadapi frustasi, menjaga agar beban stres tidak menghalangi kemampuan berpikir dan berempati sehingga dapat menjadikan sebagai sumber energi. Kecerdasan emosi memiliki peran penting untuk membantu dalam menjalankan tugas individu dan menghadapi berbagai macam permasalahan. Individu dengan kecerdasan emosi yang baik diharapkan akan memiliki daya tahan yang baik dan mampu melakukan manajemen stres sehingga tidak mengganggu kemampuan berpikir dan suasana hati ketika melaksanakan tugasnya.

Dapat disimpulkan pada penelitian ini dari data yang telah dianalisis bahwa penelitian ini sejalan dan sesuai dengan teori dan penelitian terdahulu, yang mengungkapkan bahwa kecerdasan emosi dapat membantu individu untuk mengendalikan stres kerja yang dihadapi. Berdasarkan persebaran tingkat stres kerja dan kecerdasan emosi, dapat diungkapkan bahwa subjek penelitian yang memiliki kecerdasan emosi tinggi adalah yang kecerdasan emosinya rendah.

\section{Kesimpulan}

Penelitian ini menemukan bahwa terdapat pengaruh yang signifikan antara kecerdasan emosi terhadap stres kerja pada Pengajar Muda di Gerakan Indonesia Mengajar. Pengaruh yang dihasilkan dalam penelitian ini bersifat negatif yang diindikasikan bahwa semakin tinggi kecerdasan emosi maka semakin rendah stres kerja, begitu pula sebaliknya semakin rendah kecerdasan emosi semakin tinggi stres kerja. Kecerdasan emosi mempunyai pengaruh yang bersifat negatif sebesar 16,9\% terhadap stres kerja. Hal tersebut menunjukkan bahwa kecerdasan emosi mempunyai peranan yang penting dalam stres kerja. Kecerdasan emosi mempunyai peran yang penting untuk membantu Pengajar Muda dalam menjalankan tugas yang diberikan di daerah dan untuk menghadapi berbagai macam permasalahan. Pengajar Muda yang mempunyai kecerdasan emosi yang baik diharapkan dapat memiliki daya tahan yang baik dan mampu mempunyai manajemen stres yang baik, keadaan seperti itu diusahakan terjadi agar masalah yang datang tidak menganggu kemampuan berpikir Pengajar Muda di saat melakukan tugas di daerah dan dapat menguasai suasana hati dengan baik dalam melaksanakan kewajiban. 
Fitri Lestari Issom

Fiany Aprilia
Pengaruh Kecerdasan Emosi terhadap Stres Kerja pada

Pengajar Muda di Gerakan Indonesia Mengajar

\section{Daftar Pustaka}

Aminah, A. F., Saida, A. S., Retnawati, D. B., Wibawa, E. A., Sari, E. Y., \& Suwandi, I. (2016). Mengelola Keragaman di Sekolah Gagasan dan Pengalaman Guru. Center for Religious and Cross Cultural Studies.

Anisa, A. (2014). Pengaruh Konflik Peran Ganda antara Pekerjaan Keluarga terhadap Stres Kerja pada Perawat Wanita di RSUD Bayu Asih Purwakarta. Skripsi. Universitas Negeri Jakarta: Jakarta

Aprilia, A. (2014, Agustus 19) Kurangnya Pemerataan Pendidikan Indonesia. Kompasiana.com. Retrieved from https://www.kompasiana.com/kurangn ya- pemerataan-pendidikan-indonesia

Adeyemo, D, A. \& Ogunyemi, B. 2003. Emotional Intelligence and Self Efficacy as Predictor of Occupational Stress among Academic Staff in a Nigerian University. Retrieved from www.weleadinlearning.org/da05.htm

Dewimerdeka, M. K. (2015, Juni 22) Kemendikbud Targetkan Kirim 3.500 Guru ke pelosok. Tempo.co. Retrieved from

https://nasional.tempo.co/read/677080 /kemendikbud-targetkan-kirim-3-500guru-ke-pelosok

Direktorat Tenaga Kependidikan. (2008). Penilaian Kinerja Guru. Jakarta: Direktorat Tenaga Kependidikan, Dirjen PMPTK, Depdiknas.

Farhani, I. \& Novianingtyas, I. (1997). Mempersiapkan EQ semenjak usia dini untuk keberhasilan berkarier di dunia kerja. Yogyakrta: Ikatan Sarjana Psikologi Indonesia

Gerakan Indonesia Mengajar. (2016). Buku Panduan Pengajar Muda Angkatan 14. Jakarta

Goleman, D. (1999). Emotional Intelligence: Kecerdasan Emosional Mengapa EI Lebih Penting daripada IQ. (Hermaya T, Penerjemah). Jakarta: Gramedia Pustaka Utama.

Howard, S., \& Jhonson, B. (2002). Resilient Teachers: Resisting Stress and Burnout. Journal of Social Psychology of Education, 7 , 399-420.

Indonesia Mengajar. (2018). IndonesiaMengajar.org. Diakses dari https://indonesiamengajar.org

Kazi, S. S. (2013). Occupational stress, performance, and emotional intelligence: A critical review International review of social sciences and humanities, 5(1), 185-191

Kusumawati, A. S., (2009). Hubungan Kecerdasan Emosional dengan Tingkat Stres Kerja Perawat di Instalasi Rawat Darurat. Sosiohumaniora, 11(1), 35-43

Linggasari, Y. (2014, Desember 22) ICW : Guru Menumpuk di Kota, Pemerataan Gagal.CNNIndonesia.com. Diakses dari https://www.cnnindonesia.com/icwguru-menumpuk-di-kota-pemerataangagal

Medistiara, Y. (2016, Mei 13). Kemendikbud Kirim 7.000 Guru ke 93 Daerah Tertinggal dan Terluar. Detik.com. 
Fitri Lestari Issom

Fiany Aprilia

Diakses

dari

https://news.detik.com/kemendikbud-

kirim-7000-guru-ke-93-daerah-

tertinggal-dan-terluar

Novianti, N. P. (2015). Stres Kerja Ditinjau dari Kecerdasan Emosi Modal Psikologis dan Dukungan Sosial. Psikologika, 20(1), 27-38

Prabowo, S. \& Setyorini. (2005). Pengaruh Adversity Quotient, Emotional Intelligence, dan Intelligent Quotient terhadap Prestasi Kerja Karyawan Pelaksanaan. Manasa Jurnal Ilmiah Psikologi. 1(1). 12- 16

Rangkuti, A. A. (2015). Statistika Parametrik \& Non- Parametrik. Jakarta: FIP Press.

Republik Indonesia. 2005. Undang-Undang No. 14 Tahun 2005 tentang Guru dan Dosen. Presiden Republik Indonesia. Jakarta

Riyani, Y. (2012). Faktor-faktor yang Mempengaruhi Prestasi Belajar Mahasiswa (Studi pada Mahasiswa Jurusan Akutansi Politeknik Negeri Pontianak). Jurnal Eksos, 1(8), 19-25

Robbins, S. P,. \& Judge T.A. (2011). Perilaku Organisasi. Edisi 12. Jakarta: Salemba Empat

Robbins, S. P \& Timothy. A. (2008). Perilaku Organisasi. Jakarta: Penerbit Salemba Empat

Rustiana, E. R., \& Cahyati, W .H. (2012). Stres Kerja dengan Pemilihan Strategi Coping. 7(2), 149-155.

Triana, K., Rahmi, T., \& Putra, Y. Y. (2015). Kontribusi persepsi pada beban kerja
Pengaruh Kecerdasan Emosi terhadap Stres Kerja pada Pengajar Muda di Gerakan Indonesia Mengajar dan kecerdasan emosi terhadap stres kerja guru SMP yang tersertifikasi. Jurnal Ilmiah Psikologi Terapan, 3(1), $1-18$.

Vito, B., Krisnani, H., \& Resnawaty, R. (2016). Kesenjangan Pendidikan Desa dan Kota. Prosiding KS, 2(2). 247-251 